\title{
Child Position Analysis as a Criminal Actor of Homosexual in Juvenile Criminal Justice System
}

\section{Cucuk Kristiono*) and Rakhmat Bowo Suharto**)}

*) Faculty of Law, Universitas Islam Sultan (Unissula) Semarang, E-mail: cucukkristiono11@gmail.com

$\left.{ }^{* *}\right)$ Faculty of Law, Universitas Islam Sultan Agung (Unissula) Semarang

\begin{abstract}
The purpose of this study is to formulate government policies in handling children who commit crimes through the Juvenile Criminal Justice System. This study uses a normative juridical method with a library study data collection method. The results of this study indicate that the formulation policy of the Garut Police Criminal Law enforcement through the Garut District Court Decision Number 10/Pen.Pid.Sus-Anak/2018/PN Grt against children as perpetrators of homosexual crimes turns out to be treated the same as children who commit other conventional crimes such as theft. , persecution, fights and others. The decision from the court is that rehabilitation should be carried out, the handling of which is only handed over to Islamic boarding schools, meaning that there is no special treatment in rehabilitating children who commit homosexual crimes. Whereas homosexual perpetrators are deviant behavior and must get special treatment especially if they are still children with the hope of recovering, of course it is greater in the form of integrated treatment not only from the spiritual aspect, there must be treatment from the medical and psychological aspects, so that the goals of rehabilitation will be more maximally achieved. . Suggestions related to the findings of this research is the need to include articles in Act No. 11 of 2012 to regulate more specifically in the implementation of the rehabilitation of children as perpetrators of homosexual crimes.

Keywords: Children; Homosexual; Criminal Acts; Special Rehabilitation.
\end{abstract}

\section{Introduction}

Homosexual behavior in accordance with Islamic law is strongly opposed and is threatened with very severe punishment, even the first Homosexual perpetrators on Earth were punished directly by Allah SWT, namely the Sodom and Gomorrah people of the Prophet Luth AS. The incident is enshrined in the Qur'an Surah Huud verse 82. However, with the development of an increasingly modern era, it turns out that homosexual perpetrators are not decreasing, even increasing, even homosexual groups have been protected by international human rights for a long time. have allowed same-sex marriage in the constitutions of countries, such as America, the Netherlands, Sweden, Taiwan, South Africa, Argentina, Australia, the Netherlands, Belgium, Brazil, the United Kingdom, Denmark, Finland, Ireland, Iceland, Germany, Canada, Colombia, Luxembourg, Malta,

The homosexual community can continue to grow, of course, based on the effects of distribution and regeneration. This is more dangerous if they are homosexuals who are regenerating either intentionally or because of their deviant biological needs. As a threat to regeneration, minors are the easiest targets to do. 
This is more dangerous because if the child is already included in the target of regeneration, it will be dangerous for the future of the nation. Turning to try to eliminate homosexual perpetrators, hindering their development will be difficult to do. For this reason, it is necessary to have legal regulations in order to inhibit the regeneration of homosexual perpetrators in Indonesia through Rehabilitation ${ }^{1}$ against child perpetrators or victims of homosexual children.

In the Guidelines for Classification and Diagnosis of Mental Disorders in Indonesia III (Ministry of Health RI, 1998: 115) ${ }^{2}$, homosexuality is included in the category of psychosexual disorders and is referred to as egodistonic sexual orientation, i.e. gender identity or sexual preference is not in doubt, but the individual expects the other to be caused by psychological and behavioral disorders and seeks treatment to change it. This means that homosexuality is considered a disorder only if the individual is not happy with his sexual orientation and intends to change it. In most countries where homosexual behavior is considered illegal, the dominant culture is Islam, or former communist countries or former British colonies (Colin Spencer, 2004: 469-470). In Bahrain or Bangladesh homosexuality is considered illegal, and officially declared nonexistent. In Iraq the law doesn't mention that either however homosexuality was considered taboo and sentenced to 14 years in prison. In Cuba homosexuals are punishable by 3 months to 1 year in prison. In Spirus they can be sentenced to a maximum of 5 years in prison. In Pakistan, homosexuals are sentenced to life in prison.

According to a 2006 study by Counseling and Mental Health Care of Transgender Adult and Loved One, the phenomenon of homosexuality arises not only because of environmental influences. But from the point of view of mental health science, homosexuals can appear influenced by cultural, physical, sex, psychosocial and health aspects. The many causes of the emergence of the Homosexual phenomenon can be a separate study for counselors and other helper professions such as psychologists and psychiatrists who deal with these problems. The more complex the problem experienced by the counselee, the more it requires a special diagnosis of the problem. Abdul Hamid El-Qudah, a specialist in sexually transmitted diseases and AIDS at the World Islamic Medical Association (FIMA) explained that the effects of homosexuality are: ${ }^{3} 1$. Health impacts, the health impacts caused include $78 \%$ of homosexual perpetrators contracting sexually transmitted diseases. 2. Social impact, some of the social impacts caused by homosexual behavior are based on stating "a gay person has a partner between 20106 people per year. While a person's adultery partner is not more than 8 people in his lifetime."4And $43 \%$ of the gay people who were successfully recorded and researched stated that during their lifetime they had homosexual intercourse with more than 500 people, $28 \%$ did it with more than 1000 people. $79 \%$ of them said

\footnotetext{
${ }^{1}$ Rehabilitation according to the Indonesian ledger dictionary: restoring to the former (original) condition

${ }^{2}$ Departemen Kesehatan Republik Indonesia. 1998. Pedoman Penggolongan dan Diagnosis Gangguan Jiwa Di Indonesia, Edisi ke III. Direktorat Kesehatan Jiwa, dan Dirjen Pelayanan Kesehatan ${ }^{3}$ El-Qudah, Abdul Hamid. Kaum Luth Masa Kini, (Jakarta: Yayasan Islah Bina Umat, 2015, p. 65-71. ${ }^{4}$ Corey, L. And Holmes, K. Sexual Transmissions of Hepatitis A in Homosexual Men." New England J. Med., 1980, p. 435-438.
} 
that their gay partner was from someone they didn't know at all. $70 \%$ of them are just a couple of one night or few minute dates. ${ }^{5}$ This clearly violates the social values of society. 3. Impact of Education. The impact of education includes students who think of themselves as homosexuals face the problem of dropping out of school. 4. Security Impact, the security impact is even more astonishing, namely that homosexuals account for $33 \%$ of sexual abuse of children in the United States; even though their population is only $2 \%$ of the total American population. This means that 1 out of 20 cases of homosexuality is sexual abuse of children, while out of 490 cases of adultery 1 (one) of them is sexual abuse of children. ${ }^{6}$ Although current research states that the actual percentage of homosexuals is between $1-2 \%$ of the American population, they state that their population is $10 \%$ with the aim of making people think that they are numerous and influence the politics and legislation of society. ${ }^{7}$ The results of the exposure of the research above, it turns out that as many as 33\% of cases of sexual abuse in America against children are carried out by homosexuals. Meanwhile, according to the general chairman of the Indonesian Child Protection Agency (LPAI), Drs. Seto Mulyadi said that homosexuals could have been victims of same-sex sexual violence, which in the end could turn them into liking the same sex. ${ }^{8}$. Children must be given different treatment, between perpetrators of crimes and victims of criminal acts. This needs to be done because children are the next generation of the nation who should receive protection, as in children who are involved in a crime and cause children to be in conflict with the law, children who are in conflict with the law or children are in special situations ${ }^{9}$ and Children should be properly guided, directed, guarded, cared for and educated. Based on the sound of Article 28 B paragraph 2 of the 1945 Constitution ${ }^{10}$ :

"Every child has the right to survive, grow and develop and has the right to protection from violence and discrimination".

Especially in the case of sexual violence against minors of the same sex committed also by minors that occurred in the jurisdiction of Garut on October 16, $2018^{11}$ is one example of how homosexual behavior in Indonesia has been unwittingly penetrated into child offenders and this does not rule out the possibility that there are similar cases that are not reported to the police with consideration of shame and so on so that it is difficult to detect how many cases there are. This research is motivated by the implementation of Act No. 11 of 2012 concerning the juvenile criminal justice system carried out by the Garut Police and

\footnotetext{
${ }^{5}$ Bell, A. and Weinberg, M.Homosexualities: a Study of Diversity Among Men and Women. New York: Simon \& Schuster, 1978, 1978.

6Psychological Report, 1986, p. 327-337.

${ }^{7}$ Science Magazine, 18 July 1993, p. 322.

${ }^{8}$ https://www.liputan6.com/health/read/3208942/pelaku-lgbt-bisa-saja-dulunya-pun-korban, May 28, 2021 at $19.00 \mathrm{pm}$

9Jurnal Daulat Hukum Vol. 1. No. 1 March 2018 ISSN: 2614-560X, Kebijakan Hukum Pidana Terhadap Anak Sebagai Pelaku Kejahatan Psikotropika Di Kepolisian Resor Magelang

10 A Chuasanga, Ong Argo Victoria. (2019). Legal Principles Under Criminal Law in Indonesia Dan Thailand, Jurnal Daulat Hukum, Vol $2, \quad$ No 1 (2019) http://jurnal.unissula.ac.id/index.php/RH/article/view/4218

11 Preliminary research at the Garut Resort Police at the Satreskrim PPA Unit on 3 may 2021
} 
obtaining a Garut District Court Decision Number: 10/Pen.Pid.Sus-anak/2018/PN Grt where child perpetrators are in conflict with the law in Homosexual cases in their Diversion which ended in Rehabilitation or by returning to their parents, in fact in practice they are treated the same as other child offenders such as theft, persecution and so on. Most of these children in the implementation of their rehabilitation are only handed over to Islamic boarding schools, which means more emphasis on the spiritual aspect by ignoring other aspects. The author's opinion that homosexual perpetrators are deviant behaviors that must receive special treatment in handling their rehabilitation, especially when the perpetrators are children, the possibility of recovery is high, so that during the rehabilitation process as a substitute for the confinement sentence, it is necessary to carry out integrated treatment by medical experts, psychological experts and spiritual experts (religious leaders) so that the goals of Rehabilitation will be easily achieved.

Based on the description above, the purpose of this study is to formulate government policies in handling children who commit crimes through the Juvenile Criminal Justice System.

\section{Research Methods}

The research approach used in this study is a normative juridical approach. This research specification uses descriptive analysis, namely research that in addition to providing an overview, writing and reporting an object or an event will also draw general conclusions from the problems discussed. The method of analysis used is quantitative, i.e. all legal materials collected through pediatric library research will be sorted out in order to obtain legal rules for the problems formulated and then systematized so as to produce a classification that is in line with the problems of this research.

\section{Results and Discussion}

The results of the research conducted by the author uses an analytical knife with the Legal System Theory according to Lawrence M. Friedman and the Pancasila justice theory. There are 3 (aspects) discussed using the legal system theory, namely:

\subsection{Legal Structure}

In the research that the author conducted on the Garut Police through the Garut District Court decision that in the implementation of justice against children as perpetrators of homossexual crimes, it has referred to Act No. 11 of 2012 concerning the Juvenile Criminal Justice System(UU SPPA) and in its implementation guidelines refer to Government Regulation No. 65 concerning guidelines for the implementation of Diversion and the handling of children under the age of 12 (twelve). As a component or subsystem of the juvenile criminal justice system, every law enforcement apparatus, namely the Police, the Prosecutor's Office and the Court in carrying out diversion tasks must have the same objectives as referred to in Article 6 of Act No. 11 of 2012 concerning the 
Juvenile Criminal Justice System. Where the three components are combined in one container which is often called the Criminal Justice System, it must be able to work in synergy to build a legal system that provides a sense of justice and legal protection for children. ${ }^{12}$ The process carried out by the Garut Police to immediately reach a consensus on the families of the victims and perpetrators with reference to the implementation of legal structural diversion has been fulfilled, however, there are weaknesses in Act No. 11 of 2012 concerning SPPA, here the author considers that Garut Police investigators ignore the essence of the problem, namely that homosexual crimes are deviant behavior and of course their rehabilitation must be done specifically, however, due to the limited ability of Garut Police personnel and Garut District Court, no distinction is made from other criminals.A law enforcer in carrying out legal procedures for sanctions for children who are in conflict with the law or in this special situation, must use a special paradigm. In law enforcement against children who commit crimes. Different treatment with adults, who commit crimes. Everything is clearly based on the principle of the best interest of the child. As mandated in international conventions on children's rights. ${ }^{13}$

\subsection{Legal Content (Legal Substance)}

Criminal law, in general, functions to regulate people's lives so that public order can be created and maintained. Humans in their efforts to meet the needs and interests of their different lives sometimes experience conflict with one another, which can cause harm or interfere with the interests of others. In order not to cause harm and interfere with the interests of others in an effort to meet their needs, the law provides rules that limit human actions, so that he cannot do as he pleases. ${ }^{14}$ There are 2 (two) categories of children's behavior that put them in conflict with the law, namely: 1 . Status offender is a child's delinquent behavior which if committed by an adult is not considered a crime, such as disobeying, skipping school or running away from home; 2 . Juvenile delinquency is a child's delinquent behavior which if committed by an adult is considered a crime or violation law. ${ }^{15}$ The substances regulated in this law (Act No. 11 of 2012) include, among other things, the placement of children undergoing a judicial process that can be placed in the Child Special Guidance Institution (LPKA), and the most basic thing in this law is a strict regulation. concerning Restorative Justice and Diversion, which is intended to avoid and keep children away from the judicial process so as to avoid stigmatization of children in conflict with the law and it is hoped that children can return to the social environment naturally. In carrying out the research, the author found a rare case until he got a determination from the

\footnotetext{
${ }^{12}$ Fiska Ananda, Jurnal Daulat Hukum Vol. 1. No. 1 March 2018 ISSN: 2614-560X, Penerapan Diversi Sebagai Upaya Perlindungan Hukum Terhadap Anak Pelaku Tindak Pidana

13I Dewa Putu Gede Anom Danujaya, Jurnal Daulat Hukum Volume 1 Issue 1, March 2018 ISSN: 2614-560X, Formulasi Model Sistem Pemidanaan Anak Di Indonesia

${ }^{14}$ Aan Hardiansyah, Jurnal Daulat Hukum Vol. 1. No. 1 March 2018 ISSN: 2614-560X, Tindak Pidana Kekerasan Dalam Proses Belajar Mengajar Ditinjau Dari Perspektif Hukum Pidana Dan UndangUndang Nomor 14 Tahun 2005 Tentang Guru Dan Dosen

${ }^{15}$ Andri Winjaya Laksana, Jurnal Pembaharuan Hukum Unissula Volume IV No. 1 January - April 2017, Keadilan Restoratif dalam penyelesaian perkara Anak yang berhadapan dengan Hukum dalam Sistem Peradilan Pidana Anak
} 
District Court that occurred in the jurisdiction of the Garut Resort Police in the form of a Homosexual Crime with the perpetrator and victim both still minors. One solution that can be taken in handling cases of child crimes is the restorative justice approach, which is carried out by diversion. Restorative justice is a settlement process carried out outside the criminal justice system by involving victims, perpetrators, families of victims and perpetrators, the community and parties with an interest in a crime that occurred to reach an agreement and settlement. The diversion process carried out by the Garut Resort Police Investigators for homosexual cases involving minors has succeeded in carrying out the agreement and diversion can be carried out. However, the findings in the study that after diversion was carried out and had a decision from the court that the child as the perpetrator carried out rehabilitation, but in the rehabilitation activity the handling was only carried out on the spiritual aspect, namely placing in a boarding school designated in the diversion agreement. Even though homosexual behavior in an effort to recover it, apart from the spiritual aspect, it also needs to be handled from the psychological and medical aspects, meaning that there needs to be an integrated treatment during the rehabilitation process.

\subsection{Legal Culture}

In terms of legal handling of homosexual offenders committed by minors if it is associated with the legal system in the aspect of legal culture, it can be concluded that there are actually many homosexual perpetrators in Indonesia, but very few are exposed to the media, so it should be watched out. With regard to legal sanctions against homosexual perpetrators by minors at this time, it is necessary to improve the rules. Children as homosexual perpetrators in the current justice system are equated with other child crimes. Even though there are special homosexual perpetrators ${ }^{16}$ because in his behavior is also special or unusual, namely liking the same sex. At this time the regulations regarding homosexual perpetrators are also not firm, adult homosexual perpetrators with adults cannot be criminalized. Meanwhile, homosexual perpetrators by minors, the handling of diversion is still standard ${ }^{17}$ and there is no specialization in the sense that it is still treated the same as other child crimes. The target for healing seems to have been neglected, of course this sociologically can be a threat to its spread, not to mention how to handle the victims. This is certainly ironic when compared to the rapid development of homosexual behavior in Indonesia. And we need to realize together that the regeneration or development of the spread of Homosexual actors is a necessity. Meanwhile, adult homosexuals were, of course, also children. So herein lies the problem that must be touched by the government, namely children starting with being handled specifically by homosexual perpetrators by minors, because the current legal sanctions policy has not touched the substance of the problem.

\footnotetext{
16 https://jagokata.com/arti-kata/kekhususan.html, Arti kata kekhususan menurut KBBI adalah sifat khusus; keistimewaan, tidak umum, downloaded on June 2, 2021

17 https://kbbi.web.id/standar-2, pengertian standar adalah ukuran tertentu yang dipakai sebagai patokan, dan patokan perlakuan sistim peradilan anak terhadap pelaku tindak pidana homoseksual oleh anak dibawah umur di Indonesia adalah sama dengan anak dibawah umur yang melakukan kejahatan lainnya. Downloaded on June 2, 2021
} 
The punishment of children as perpetrators of homosexual crimes in the construction of Pancasila justice is in the first and fifth precepts of Pancasila are Belief in One God and social justice for all Indonesian people and their elaboration in article 29 of the 1945 Constitution where the State guarantees that every citizen carries out his religious teachings, and there are 6 (six) religions in Indonesia, all of whom do not agree with marriage. Same-sex. Meanwhile, the majority religion in Indonesia is Islam which strongly rejects homosexual acts. The Indonesian nation, which has the ideology of Pancasila, will certainly not agree that Indonesian citizens are free to express individual freedom because they are limited by social and state ethics in the principles of Just and Civilized Divinity and Humanity. Article 28J of the 1945 Constitution also explicitly provides restrictions on every citizen in expressing their freedom. According to the author, justice is the goal of establishing legislation that has not been achieved because homosexual acts are a deviant act and if the perpetrators are children, then healing can still be done as usual when handled properly. If these rules are still maintained, then justice for children who are in conflict with the law in homosexual cases is difficult to fulfill according to Pancasila in the fifth precept, namely social justice for all Indonesian people.

While Homosexuals in the perspective of Islamic Law is a big problem whose impact is very dangerous for mankind, especially the future generation of the Indonesian nation. Islamic teachings strictly prohibit this deviant behavior because it is not in accordance with human nature, as Allah SWT says:

"Why do you come to the kind of men among the people, and you leave the wives your Lord made for you, even though you are transgressors" (Surat Ash-Syu"arâ": 165166)

"And (we have also sent) Lut (to his people). (Remember) when He said to them: "Why do you do that fâhisyah (heinous) deed, which no one (in this world) has ever done before you?' Verily you come to men to release your lust (for them), not to women..." (Surah Al-A"râf: 80-81)

The Messenger of Allah said,

"Anyone who finds a male homosexual, then kill the culprit." (Narrated by Abu Dawud, At Tirmidhi, An-Nasai, Ibn Majah, Al-Hakim, and Al-Baihaki).

The Qur'an and the Hadith above have clearly and clearly explained that the practice of homosexuality is a major sin and has very severe sanctions in the world. If it is not imposed in this world, it will be imposed in the hereafter.From this it is very clear that homosexual behavior is contrary to human nature and the teachings of Islam, of course.

\section{Closing}

The results of the research conducted by the author using an analytical knife with Legal System Theory according to Lawrence M. Friedman and Pancasila Justice, Legal Structure, namely that many law enforcement officers still do not understand the essence of the problem of deviant behavior in the form of homosexual crimes, so that in its Diversion still equated with other child crimes plus the role of BAPAS and social worker institutions is also not optimal in monitoring the development of the child. In terms of Legal Substance, the handling 
is more sectoral in nature so that the expected final result from Rehabilitation, whether the child is cured or returned to normal, has not been maximally achieved due to the absence of special integrated handling from Health, Psychological and Religious aspects.Failure in handling the rehabilitation of children as perpetrators of homosexual crimes sociologically can be a threat to its spread, not to mention how to handle victims who may be infected from the behavior of the perpetrators.

\section{References}

\section{Journal}

[1] A Chuasanga, Ong Argo Victoria. (2019). Legal Principles Under Criminal Law in Indonesia Dan Thailand, Jurnal Daulat Hukum, Vol 2, No 1 (2019) http://jurnal.unissula.ac.id/index.php/RH/article/view/4218

[2] I Dewa Putu Gede Anom Danujaya, Jurnal Daulat Hukum Volume 1 Issue 1, March 2018 ISSN: 2614-560X, Formulasi Model Sistem Pemidanaan Anak Di Indonesia

[3] Andri Winjaya Laksana, Jurnal Pembaharuan Hukum Unissula Volume IV No. 1 January - April 2017, Keadilan Restoratif dalam penyelesaian perkara Anak yang berhadapan dengan Hukum dalam Sistem Peradilan Pidana Anak

[4] Rendy Surya Aditama, Jurnal Daulat Hukum Vol. 1. No. 1 March 2018 ISSN: 2614-560X, Kebijakan Hukum Pidana Terhadap Anak Sebagai Pelaku Kejahatan Psikotropika Di Kepolisian Resor Magelang

[5] Fiska Ananda, Jurnal Daulat Hukum Vol. 1. No. 1 March 2018 ISSN: 2614560X, Penerapan Diversi Sebagai Upaya Perlindungan Hukum Terhadap Anak Pelaku Tindak Pidana

[6] Aan Hardiansyah, Jurnal Daulat Hukum Vol. 1. No. 1 March 2018 ISSN: 2614560X, Tindak Pidana Kekerasan Dalam Proses Belajar Mengajar Ditinjau Dari Perspektif Hukum Pidana Dan Undang-Undang Nomor 14 Tahun 2005 Tentang Guru Dan Dosen

\section{Books}

[1] Adami Chazawi, 2002, Pelajaran Hukum Pidana Bagian 1: Stelsel Pidana, Tindak Pidana, Teori-Teori Pemidanaan dan Batas Berlakunya Hukum Pidana, PT Raja Grafindo Persada, Jakarta

[2] Ahmad Fauzan, 2009, Peradilan Umum, Peradilan Khusus, dan Mahkamah Konstitusi, PT Kecana

[3] Bell, A. and Weinberg, 1978, Homosexualities: a Study of Diversity Among Men and Women. New York: Simon \& Schuster

[4] C.S.T Kansil dan Christine S.T Kansil, 2007, Pokok-Pokok Hukum Pidana, PT Pradnya Paramitha, Jakarta

[5] Corey, L. And Holmes, K. 1980. Sexual Transmissions of Hepatitis A in Homosexual Men." New England J. Med.

[6] Departemen Kesehatan Republik Indonesia. 1998. Pedoman Penggolongan dan Diagnosis Gangguan Jiwa Di Indonesia, Ed. III. Direktorat Kesehatan Jiwa, dan Dirjen Pelayanan Kesehatan

[7] El-Qudah, Abdul Hamid. 2015. Kaum Luth Masa Kini, Jakarta: Yayasan Islah Bina Umat 
[8] Marsaid, 2015, Perlindungan Hukum Anak Pidana Dalam Perspektif Hukum Islam (Maqasid AsySyari'ah)

\section{Internet}

[1] https://jagokata.com/arti-kata/kekhususan.html, Arti kata kekhususan menurut KBBI adalah sifat khusus; keistimewaan, tidak umum, accessed on 2 June 2021 at $14.00 \mathrm{wib}$

[2] https://kbbi.web.id/standar-2, pengertian standar adalah ukuran tertentu yang dipakai sebagai patokan, dan patokan perlakuan sistim peradilan anak terhadap pelaku tindak pidana homoseksual oleh anak dibawah umur di Indonesia adalah sama dengan anak dibawah umur yang melakukan kejahatan lainnya. Accessed on 2 June 2021, at $17.00 \mathrm{wib}$

[3] https://www.liputan6.com/health/read/3208942/pelaku-lgbt-bisa-sajadulunya-pun-korban, 28 May 2021 at 19.00 wib 